\title{
Psycho-Social Effects of Violence, Terrorism, and War on Gender in South-East Region, Nigeria
}

\author{
Ihedioha, Love Nkem \\ National Institute for Nigerian Languages, Abia State, Nigeria
}

\begin{abstract}
This paper offers a broader look at the psychosocial effects of violent, terrorism, and war on gender in the South-East region of Nigeria. In the last two decades, the people of the South-East region called "Ndi Igbo" witnessed all kinds of violence, terrorism, and some religious and political war that has greatly influenced the psyche of all across the globe. The recent kidnapping incidences and the political violence in the area gave terrorism a new dimension and trend. The study shows a greater danger not only to the indigenous people of "Ndi Igbo”, but to all Nigerians. The paper analyzed and explained the Igbo crisis within the frustration-aggression and structural functionalist theories and argued that frustration is the bane of the recurrent violence in the region. The paper employed a mixture of qualitative and quantitative survey research based on secondary data and key informant interviews (KIIs) as tools. The paper also argued that most of the issues that generated the frustration anger and the murderous actions is injustice and marginalization, and on the premise that the government has ignored the environmental security that led to the problems under discourse.
\end{abstract}

Keywords: violence, terrorism, gender, psycho-social issues, frustration-aggression, structural functionalism

\section{Introduction}

Nigeria has been greeted with series of political and civil violence, terrorism, and war since after independence in 1960. Women, youths, children, and the elderly had been worst heated. According to Salawu (2010), Nigeria is a multinational state that has between 350-500 linguistic groups and fairly populated by half Christians and Muslims. Political violence, civil war, terrorism, and kidnapping are still affecting every section of the country worst still, in the South-East Nigeria during and after the Nigerian-Biafra War.

Amnesty International (2004) noted that human rights situations across the region of Africa is characterized by widespread armed conflict, war, and political repression (violence) in all, women are at risk end. The United Nations report on the state of the world population in 2000, noted that gender based violence, constitute a lifelong threats for millions of women and girls across the globe (United Nations, 2000b).

The 1966-1970 Civil War left most women widows, many men widowers, lost of lives, rape, injuries, untold hardships ranging from socioeconomic stress to psychosocial imbalance. Research shows that $60 \%-80 \%$ of the people exposed to war and political violence directly or indirectly suffered symptoms of post traumatic stress (Chinwokwu \& Arop, 2014). Research findings indicates that mere living in a violent prone area, where the media is filled with images and reports of horrible violence destruction as we are witnessing today, can

Ihedioha, Love Nkem, Ph.D., Department of Teacher Education, National Institute for Nigerian Languages. 
result in people experiencing symptoms of post traumatic stress, children, women, and the elderly are more at risk than able bodies men during political violence and war. The effects of the civil war and the ongoing abduction/kidnapping issue and the recent political violence in the last two decades have left an untold hardship to the gender. These insurgencies have produced many widows, bastards, orphans, homeless persons, and increased mental health citizens and hard of hearing, who among the "Ndi Igbo" are called the "artilary", because they are hard of hearing.

\section{Conceptualization of Terms Understanding Crime Insurgency and Insecurity Threats (Kidnapping,} Terrorism, Violence, and War) in the South-East Region, Nigeria (Ndi Igbo)

In 2007, the human rights watch (HRW) estimated that a minimum of 30 Nigerians were killed in political violence in the 2007 elections, a lot higher than the report of 2003 elections violence. The European Union Election Observation Mission (2007), reports that about 200 people died in political violence within two weeks among April 21, 2007 election. The South-East region has been enduring harsh environmental condition since after the Nigerian Civil War. The region have been left to be a battle ground which because of the regions cries, has pushed the federal government of Nigeria to situate a group of the armed men called "Operation Piton Dance” in Abia State to check mate the criminality atrocities in the region since 2017 till date, yet people are kidnapped and some are killed.

Studies have shown that political violence and war have negative effects on the children ranging from heightened aggression, violence, revenge seeking, anxiety, depression, withdrawal, sleep disorder, fear and panic, poor school attendance, and performance and involvement in criminal violence (Sagi-Swartz, Seginer, \& Adeen, 2008; Quota, Runmaki, \& El-Sarrai, 2008). Children were found to be victimized by different types of political violence and war, especially where the families resides. Child soldiering is rampant in African states and this is as a result of war, political violence, war violence, and others. In some African countries, like Angola, Ethiopia, Uganda, Congo and Algeria, to mention but a few children are seen to be recruited into the military camps and actually carry gun to kill their fellow citizens (Chinwokwu \& Arop, 2014). During the Nigerian Civil War of 1966-1970, the Biafra army recruited boys called "Boys Company". The boys were given catapult to scout for birds and ants in pretence to locate the Nigerian army hide outs.

The April 2011 general election in Nigeria claimed over 800 lives and over 65,000 persons displaced especially (Human Rights Watch, 2011). Nigerians are still being ravaged by the source of insurgency across the country. Political and war violence are orchestrated by the attitudes and utterances of the political leaders who believes that election is won by the use of political thugs and violence. Obasanjo (2002, p. 50) asserted that we fight and sometimes shed blood to achieve and attain political power because for Nigerians, the political kingdom has for too long been the gateway to economic kingdom. Omoweh and Okanya (2005, p. 303), when they said political competition for control of state and its political power is now a bloody warfare as the state holds the key to wealth, one could understand why there is too much tension and insecurity in the country as 2015 general election approaches.

Kidnapping of all manner of persons has gained ascendency in Nigeria. In the last decades, the volatile oil rich regions of the Nigeria Delta of South-South, witnessed this phenomenon on a large scale with the target being mostly expatriates and Nigerians in the oil industry. Kidnapping spread throughout the country extending to places as far as Kaduna in the far Northern Nigeria. Kidnapping has since then earned the South-South and South-East, the kidnappers play ground of Nigeria. Kidnapping seems easier compared to other forms of serious crimes (Ngwama, 2014, p. 133). For instance, a group of criminals armed with guns and cell phones 
will apprehend an unsuspecting victim(s) and drag him with eyes closed into a secluded spot and begun to make phones. The police with a mandate to provide security for the people are often unprepared for the task at hand as they are poorly trained and equipped (Davidson, 2010).

The abductors and their families are traumatized by the ordeal of their activities. The general state of insecurity in some parts of the country has no doubt reached a stage where virtually everybody is now worried the direction the region is going. Though Nigerians are paying the price of bad and poor governance and failures of leadership in the country, kidnapping insurgence affects all but mainly the gender especially women and girls as the abductors rape them in turns and at times mostly loss their lives in the process. The elderly too are traumatized at their actions and mainly, loss their lives before they are released when abducted (Amaraegbu, 2011).

By its prevalence in the country, kidnapping become a generic word both in public and private discuss. According to Ngwama (2014), kidnapping appears to be an emerging concern in Nigeria though not a new phenomenon. Since the 17th century B.C., the unfriendly work of kidnapping has been used to practice stealing of children for use as servants or labourers in the American colonies. But today, it has come to mean any illegal capture and detention of a person or persons against their will regardless of age.

The motive of the kidnappers has been found to range in criminality for several complex reasons: unemployment, idleness, vengeance, rituals, monetary gains, and political reasons. The first act of kidnapping started in Nigeria when the militants of the Niger Delta (South-South region) took hostage of their region to protest the inequality. The militants complained that Nigeria is built at the expense of their region which serves as the cash cow for the whole country. As the kidnapping insurgency escalated, it led to a very disturbing national and sub-region security concerns. It spread from the volatile oil rich regions on a large scale throughout the country and extended to the far north.

In 2014, all the kidnappings occurred in the South-East and Niger Delta regions, which habour the African's biggest oil and gas industry. South-East Nigeria (Abia State) in particular has the most incidents with 110 people taken hostage. This exercise gained the South-East and South-South regions "kidnappers play grounds of Nigeria” (Ngwuma, 2014). For instance, the insurgency reached a new dimension of crime when the issue of payment for ransom in millions of naira was introduced. This was obvious in the kidnapping of the chairman of the Nigeria Union of Journalist (NUJ) Lagos state chapter Wahab Oba and others: the secretary, Sylva Emeka Okereke, Zonal Secretary NUT Lagos, Adolphus Okoronkwo, Shola Onyeyipo of the voice of Nigeria (VON) and their driver, Azeez Abdulrauf, along Aba Ikot Ekpene road on their return from Uyo, Akwa Ibom State capital Nigeria after attending a three days national executive council meeting organized by the NUJ.

The activities of the corrupt Nigerian political process left these regions poor and under developed producing in effect unintended consequences that has created large class of young men with no hope of legitimate work that would fulfill their ambitions. These ones were easily recruited into violence (Human Rights Watch, 2003, p. 2). According to Bayant (2009, as cited in Amaraegbu, 2011), who talked about the idea of accumulation, opening up of opportunities of social mobility and enabling the holder of power to set himself up; the 2003 elections speak for itself and showed how State Governments in the regions recruited armed militias to carry out widespread electoral fraud (Walker, 2008). For instance, the former leader of Niger Delta People's Volunteer Force (NDPVE), Asari Dokubo linked the former governor of Rivers State Peter Odili and Abuye Sekibo, former Federal Transport Minister, Austin Opara, ex-deputy Speaker of the Federal House of 
Representatives and some of the Odili's aides as sponsors and financiers of the terror gangs. They were formed and empowered before the general election of April 2003 to ensure the victory of the ruling party (PDP) by any means (Niger Delta Project for Environment, Human Rights, and Development [NDPEHRD], 2004, pp. 5-6). Similarly, Abia State had a crude type by a notorious kingpin, Obinna Nwankwo known as "Osisikankwu”. He was founded by the Rivers State War Lord Ateke Tom. Osisikankwu held Abia State and the environs hostage unleashed terror, pains, and aguish on the hopeless citizens. Surprisingly, when he was eventually killed by the special task force from the 82 division of the Nigerian army, Enugu, and taken to the Government House Umuahia, he was buried with a government provided casket (Sun News, 2010).

The above illustration portrays the fact that an election in Nigeria is not by electoral consensus rather an instrument of force that determines the winner. The role of providing security has been largely ignored and the people of Nigeria no longer enjoy maximum security. Today, the effects are the concern of the churches, mosques, schools markets, homes, and the highway users. The abductors and their families are traumatized by their ordeals. Hardly can people sleep because of the fear of being robbed or kidnapped.

Though political violence has a global phenomenon, there is no definite or common definition for the term. Attempt to define the phenomenon has aroused arguments among the intellectual communities (Chinwokwu \& Arop, 2014). Political violence is a violence that is committed in the context of a political conflict or that which can be related either through its cause or motive to political issues. He maintained that political violence is public rather than private. But according to Cohen (2006, p. 925), political violence is a legitimate, justifiable means of way, a long term ideological bottle neck against a hostile government. Political violence has been classified as official violence against citizens (police brutality); violence that results from the nature of the state (patrichial nature) and violence resulting from the nature of political structure (politics of bitterness) (Okolie, 2008). However, others classified political violence as counter-insurgency, terrorism, rioting and civil war, coup detat (Theodore, 1998); revolution, rebellion, and insurgency (Cohen, 2006).

Some eminent scholars have argued that terrorism should be excluded because of the subjective definition attached to it (Said, 1988; Jenkins, 1990). According to Young (1977), political violence is justifiable when it is interpreted in the concept of just war in which there is a failure to grant citizens effective means of peacefully gaining redress against tyrannical abuse of power; when these matters are not respected re-voluntary activity will be justified if there is a strong likelihood that the government can be toppled without ensuring tyranny or anarchy and bloodshed of an inordinate extent.

Various analysts (Ogundele, 2008; Osaghae, 1995; Cohen, 2008) have used rebels, insurgents, militants, terrorism, freedom fighters, and so on, to describe the crisis and those behind it. The very diversity of views reflects the enormous variety of efforts to understand and observe the problem. Eminent scholars of foreign policy issues have argued that in that regions of the world, including the Middle East, different opinions regarding insurgency or groups are shared. For instance, while the U.S. classified the Lebanon-based Hezbollah-a pro-Syrian movement, reportedly funded by Iran, as a terrorist group, the European Union on the other hand resists the pressure to outlaw Hezbollah as a terrorist group (Cohen, 2008). Conceptualization is better understood in the context of trends and patterns based on the tactics and strategy the perpetrators used in conflicts. The South-East region crisis appears to be the acts of insurgency. They may not be terrorists but used tactics of terror. According to Golder and Williams (2004, p. 270), attempts to develop a generally accepted legal definition of terrorism have failed. The failure is made possible because of the individual variability both 
in the kinds of conflicts and in their methods of operation.

Conflicts occur under very many different circumstances. It takes a bewildering variety of forms and has been argued that security ought to be appreciated beyond mere military protection of state territorial integrity and interest (Buzan, 1997, p. 5). According to Golder and Williams (2004, p. 272), lack of consensus of what constitutes terrorism points to its escapable political nature, perhaps best encapsulated in the aphorism that one's persons terrorist is another person's freedom fighter. A more important elaboration described it as a form of political behaviour resulting from the debates choice of a basically rational actor, the terrorist organization (Crenshaw, 1981, p. 380). Thus, terrorists are normally triggered by some form of oppression-real or imagined, which precedes the terror act that allows the proprietors to rationalize their actions.

Terrorism includes a range of social and political problems whose behaviours appear to be abnormal. Then, a functional clarification, an unconventional political violence, or the threat of political violence meant to have an impact on both the immediate victims and the audience that is carried out by non-state actors and/or clandestine state agents (Brown, 2007, p. 30). Brown's clarification points clearly in the direction that non-state-actors and/or clandestine state agents use illegal exposure devices to create impact on both the immediate victims and the audience.

If we combine both statements of Burton and Brown, we can conclude that the activities of the insurgences in the southern Nigeria, constitutes a form of political behavior, resulting from the deliberate choice of basically national actions. Thus, both the militants and the kidnappers are arms acquired illegally to engage in an unconventional warfare in order to side step the limits placed on them by the Nigerian government. Over time, their tactics evolved from crude kidnapping for ransom operations to a more supplicated and effective methods that combine hostage taking and bombings (National Consortium for the Study of Terrorism and Responses to Terrorism [START], 2008). It has been argued that victims or objects of terrorist attack have little intrinsic value to terrorism but represent a larger human audience whose reactions the terrorist seek (Crenshaw, 1981, p. 376). The panic its impact produces and creates on the people makes more sense to the terrorists than the real victims of a terrorist incident.

There are common elements identifiable among the majority of functional definitions of terrorism. According to various descriptions, terrorism is characterized by some common strings-political, psychological, coercive, dynamic, and deliberate action (Federal Emergency Management Agency [FEMA], 2009). Terrorism which always pleads political cause involves the committing of terrible acts intended to cause political change.

We may tend to agree that terrorism is an object of political violence which is regarded as war, is a state of organized, armed and often prolonged conflict carried on among states, nations, and other parties. It is often intensive and characterized by extreme aggressive, social disruption and followed by high mortality which involves all genders (Merriam Webster's Dictionary, 1998). Simply put, war is a military conflict between nations and or parties.

Armed violence otherwise known as war is defined as the "intentional use (threatened or otherwise) against oneself, another person or against a group or community of any material thing that is designed, used, or usable as an instrument for inflecting bodily harm that either result in injury, death, psychological harm, mal-development, or deprivation” (Perouse de Montcles, 2011, p. 7).

Conflict is described as the resort to the use of force and armed struggle in the pursuit of incompatible and particular interest and goals by contending groups or individuals (Oraegnunam, 2006).Conflict is inevitable in 
social life's process and even in well developed human societies like United States and Britain. Conflict may be described also as a period of intense pursuit of incompatible goals by different groups. It must be stressed that in Nigeria, there are conflict of interest among group-political, economic regions, or social arena. All have in most times ended violently resulting to great casualties. According to Nwolise (1997), conflict refers to clash, contention, and confrontation, a battle of struggle or quarrel among two or more individual, group, or nations. According to Zartman (1991, p. 300), conflict is the exhibition or expression of incompatibility though conflict may become violent; violence is not inherent aspect of conflict but a potential form which conflict may take.

Gender is a term that has psychological and cultural connotations, if the proper terms for sex are male and female. The corresponding terms for gender are masculine and feminine. These later terms might be quite independent of biological sex (Haralambos, 2007, p. 93). Scholars refer to gender as culturally or socially constructed patterns of behavior which may be attached to the sexes. Gender is a social construction which is culturally determined. According to Idyorough (2005, p. 2), gender issues are not women issues alone, they are issues of men and women and the attendant power relations among the sexes. However, political violence and war negatively impact on the psychosocial makeup's of both genders in the South-East Nigeria.

\section{Methodology}

The paper employed a mixture of qualitative and qualitative survey research methods based on secondary data and key informant interviews (KIIs) as tools involving some elites who fully fought the Nigerian-Biafran Civil War of 1966-1970, either as army officials or boys company (youth militia) and also some lecturers from National Institute for Nigerian Languages (NINLAN), Aba, Nigeria. The paper also used online data basis, journals, and materials, which served as secondary means of reports on political violence and war reviewed that aimed to promote the constructive debate and guided analysis.

\section{Frustration-Aggression Perspectives and the Issues in the South East Region, Nigeria (Ndi Igbo)}

Studies have shown that conflict is inherent in every human society. According to Dahrendolf (1958), peace can exist separately from conflict, violence and war, however, armed conflict (war) is the only one aspect of violence which is physical, open, and direct. Galtung (1969) contained that a society cannot be described as peaceful where structural poverty, exclusion, intimidation, oppression, want, inequality, unemployment, fear, and all types of psychosocial pressures still constitutes the society's problems.

Sociologically, peace can be reviewed as a condition of social harmony in which there are no social antagonisms, in which case individuals and groups are able to meet their social needs and expectations, such as food, cloth ... and other social amenities for a worthy life. The implication is that where these are lacking, there is contention between those who have and those who have not for the available resources in the society. Three basic theories: frustration, aggression, and structural functionalism could be derived from the above and the paper will be discussed on these theories.

The frustration-aggression theory is associated with Donald, Millar, Doob, Mowrer, and Sear (1939, p. 1), the core assumption of which is that aggression is always a consequence of frustration. They argued that individuals are motivated to achieve life ambitions and fulfill destiny, but when these expectations are thwarted frustration sets in. They also assumed that the existence of frustration always leads to some form of aggression. However, the argument may have failed to differential between investigation to aggression and the real incidence of aggression, but the paper agrees that frustration provokes inquiries to various types of 
consequences of having been exposed to an extremely frustrating condition sufficient to provoke the experience of hopelessness.

Simplistic analysis of the reasons for hostility in the region for instance is the idea that the Igbos are at odds with the Hausas and this has distracted attention from what many consider the major problem. It is time that schism exists among the various regions and ethnic groups, but frustration accessioned as a result of a sense despair and deprivation, environmental, and developmental issues.

The paper recognizes that the competition between the next and the emergent powers of the east in the struggle for energy resources can be considered factors (Amaragbu, 2011). For instance, the response of the Niger Delta youths to the Nigerian states neglect and apathy of oil multinationals in the Eastern regions radicalized the militants and kidnappers to violent.

According to the New Partnership for Africans Development (NEPAD) (2008), the lack of property in the handling of oil revenues speaks for itself. Thus, Nigeria presents a remarkable paradox of an enormously wealthy nation both in potential and real terms, servicing as home to the third largest concentration of poor people in the world (Amaraegbu, 2011). The country normally makes sustainable revenue from the oil and gas industry but has apparently failed to provide basic services for its people (NEPAD, 2008, p. 33). Agreeing with the above contention, the paper wishes to explore other issues if only because they contain immediacy and concrete relevance. The organization highlighted Nigerian history of competition and poor governance. So, the greatest challenge confronting the country is how to transform and manage its enormous wealth from oil and gas to achieve socioeconomic development (NEPAD, 2008, p. 7).

The large scale decay in the regions further strengthens the argument that infrastructural decays are among the fundamental causes of the distress that stroke militancy and kidnapping in the regions (Obi, 2009, p. 3). The reports of the technical committee on the Southern region captured the essence of the problems elaborately:

The absence of ... infrastructure(s) in a region that produces so much wealth and opportunities for the nation has continued to prick the conscience of many and contaminated opportunities for building national harmony and a sense of citizenship. (Technical Report on the Niger Delta (1), 2008, p. 51)

According to the Human Rights Watch (2003, p. 3), the political environment is one in which the Nigerian government has failed to ensure that the people who live in the oil producing areas actually benefits from the oil. It is even more tragic considering the attitudes of the politicians in the regions. A respondent stressed on the importance of commitment to values and pointed to the developmental challenges in the oil producing regions:

The worst is that when they come to ask us for votes, they will make some appealing promises, project some aura of fragility and fiscal responsibility, but slip into familiar ineptitude once they get the power. (Interview, Aba, January 20, 2018)

A respondent was asked if frustration could push the youths to take up to armed violence. He answered in affirmative that despite the enormous amount of money given to states as subvention wage bill and so on, all the state workers are been owned up to eight months salaries. Pensioners are not paid. Teachers are worst hit (Interview, Owerri, February 10, 2018).

Respondents were asked if frustration could be the reason the youths take to armed violence. Responses were obtained from a total of 50 persons of who 42 (84\%) answered in the affirmative, while eight respondents (16\%) reported having experienced hardship through marginalization and negligence from the government. 
All the respondents 50 (100\%) said, despite huge amount of money purportedly spent by the Federal Government, South-East region still remained deplorable. (Interview, Owerri, March 20, 2019)

Frustration leads to aggression and aggression always implies that frustration has occurred at some precious times. When individuals are subjected to a situation of alienation and extreme frustration, it makes them to act unusually aggressive. In the Southern Nigeria, this situation has led to the creation of group alliances and allegiances aimed at confronting the perceived injustice. This theory views the idea of comparative lack as an obvious gap between value expectation and value capabilities or the lack of a need satisfaction is defined as a gap between aspiration and achievement.

Hence, when there is a disparity between the level of expectation and achievement tension builds because of the pressure of a dashed hope. When this inability on establish connection between both levels persist for a long time, frustration sets in. According to Dollard et al. (1939, p. 2), one of the easiest lessons human beings learn as a result of social living is to suppress and retain their overtly aggressive reactions. This shows that an individual who has endured deep-rooted economic hopelessness may transform from a frustrated individual to an aggressive person, which in most cases, end up in violent actions. So, when a person who is deprived of basic aspirations and who, as a result, suffer overwhelming sense of frustration is inclined to respond aggressively towards those perceived to be frustrated attempts at Living a good life.

According to Berkowitz (1989, p. 69), a distinction between attitudinal aggression and behavioural aggression is direct results of sustained frustration, thus, he acknowledged that aggression is a common example of the link between terrible motivation and repulsive emotions and fear. According to Berkowtz (1989), people prevented from reaching a desired goal become aggressively inclined, especially when the interference is believed to be improper like a violation of socially accepted practice or is perceived as a personal attack.

According to Gurr (1970, p. 24), the potential for collective violence varies strongly with the intensity and scope of relative deprivation among members of a collectivity. He said that the primary source of the human capacity for violence appears to be the frustration-aggression mechanism. The majority of the informants (95\%) put the situation into proper perspective:

Our mortal sin is that we are Igbo's asking for freedom, our region is a site of despair, appealing poverty, and anguish, from frustration to agony, we are marginalized at government positions. The whole of Igbo land has no single good road, no good water, and no steady electricity. Out of frustration, our people remembered their faith during the war, and therefore, the youths agitate for Biafran nation. As they protest, the world was told that Biafran youths are terrorists group: the origin of armed soldiers (piton dance group) sent to crush them. (Interview, Aba, February 12, 2018)

The respondents explicitly stated what the region's core interest, concerns, and dilemmas are and why they should be allowed to have their own nation. Each time they ask for independent state of Biafra, there will be shooting on the youths and mass killing and destruction of properties and goods. Hidesmen and their flocks destroy farm lands, women and girls are raped in their farms by these hardest men, women now fear going to the farm alone. All these have adversely affected the people's capacity to engage in meaningful farming activities, which has drastically reduced agricultural output in the regions.

As a result, there has been a great decline in regional economy as farmers are unable to handle the high cost of living. This, however, has triggered more vigorous aggressive tendencies in the regions. (Interview, Umuahia, February 20, 2018)

Structural functionalists looked at conflict as a function of the structural constituents of the society. Hence, 
poverty, unemployment, crime, social inequality, marginalization, relative deprivation, corruption, injustice, oppression, and exploitation are regarded as sources of conflict which could lead to political violence and war has a variety of divesting effects on gender ranging from physical and psychosocial, the following are some major effects of violence, terrorism, and war on the South-East region of Nigeria (the Igbos).

Studies looked at conflict in the society as a result of struggle for scarce resources (Marx, 1977). Some respondent informants (86\%) illustrated that:

Our leaders punish us with poverty, and unbearable living conditions. They set up many commissions and bring development plans but fail to implement them. The youths have no jobs; they say there are no money, yet "snake swallow billions of naira” in public offices. It is unfair. (Interview, Aba, February 20, 2018)

However, peace is achieved where existing structures perform their functions adequately, supported by the requisite culture, social norms, and value.

\section{Effects of Violence, Terrorism, and War on Gender in the South East Region, Nigeria}

Violence, terrorism, and war have a variety of devastating effects on gender ranging from physical, social, and psychological. The following are some major effects of violence terrorism and war on the South-East regions of Nigeria.

Terrorism and war are major plague of violence that has ravaged the loves of the indigenous Igbo people of Nigeria since and after civil war in 1966 till date. Nigeria recorded over 200,000 cases of death in the last two decades caused by political and religious precipitated war or violence (Soriwei, 2012; Chinwokwu, 2012c). The civil war left thousands of children orphans, while men and women ended up widows and widowers. Without records, children of both sexes are separated from their parents and many children lost their lives during the process of running away from attacks. Many children and aged were also abandoned either, because they are weak or many a time, children who cry too much were abandoned. This was the case of 1966-1967 Nigeria Civil War, and in the reprisal attacks that followed after the killing of the Igbos in the Northern states of Nigeria on and in 1990 (Chinwokwu \& Arop, 2014). The abandoned children ended up being adopted or as slaves in the hands of their masters.

One of the effects of violence, terrorism, and war on gender is the displacement of people from their native lands, starvation, hunger, malnutrition, and Kwashiokor (diseases). During violence, terrorism, and war, social dislocation and displacement affects all gender groups of all ages though women and their children suffer mostly. Families are disorganized especially with the absence of their parents. During the 1966-1970s, the Igbo children and the aged suffered malnutrition, Kwashiorkor, and diarrhea in some cases, many youths suffered permanent injuries, ranging from lots of limbs or legs and many others die for lack of medical care.

During violence, terrorism, and war, boys and girls suffer varying uncountable sexual abuses. It is a common practice to have girls and boys sexually abused, and also recruited for sexual purposes ranging from force marriage, child sex slaves, girl child marriages, and rape. Social services like education, hospital, and trade are disrupted. School buildings are destroyed and closed down. Genders of all ages would be denied basic education and their fundamental rights infringed upon. It has taken the Igbos for example decades to recover from such waste of human capital since after the war. Violence and war also create shortage of food production which would lead to great hunger and starvation that would cause such diseases like Kwashiorkor and malnutrition. Surprisingly, this is what Nigerians are facing since this present political dispensation. It is observed that the kidnapping saga in the Southern region has led many of the rich business men to abandon 
their homes and businesses, which has also disrupted trade activities and cause mass exodus of traders from the Eastern states to more peaceful states in Nigeria and other West African states like Ghana, etc.

The youths and women suffer sexual abuses and are therefore traumatized. The psychosocial effects of sexual abuses are demeaning and humiliating and affect the youths' self-esteem and left them with psychological mental problems like depression, post traumatic stress, disorders, phobia, alcoholism, drug abuse, and suicide. Others include mistrust, shame, guilt, and fear of stigmatization in the society.

\section{Recommendations}

Violence, terrorism, and war bring great danger to the development of any nation. No country thrives well under the heat of violence, terrorism, and war. A progressive nation should live under the atmosphere of peace, tranquility, and harmony. Government should endeavour to avoid dishonor and maintain peace and order, avoid things that will cause disequilibrium in the country. Government should not impose political candidates on the electorates. There should be equity and justice in all political electrons in the country.

There should be positive developmental programmes to eliminate poverty and empower youths, because youths are frustrated and are so much stressed. There is economic unbalance and inequitable distribution of wealth, which is the cause of unemployment in the country.

There should be a synergy of all security agencies to curb conflict and crime at its bud. Government must continue to engage in dialogue with all the key stakeholders involved in any conflict situation to ensure that contending issues are resolved peacefully to avoid violence, terrorism, and political war. Government must imbibe peace at all times and endeavour to avoid issues, such as mistrust, marginalization, poverty, unemployment, corruption, and equity in the country.

\section{Conclusions}

The aim of the paper is to explain the effects of violence and war on the South East region of Nigeria along the frustration-aggression and the structural functionalist theories. The paper have shown that poverty and the political process in the Nigeria government with its system of compromise, conspire with frustrating conditions like environmental security, render the youths vulnerable to aggression.

The respondents cut across age, gender, status, religious, and ethnic lines. Most of the respondents have not been subjected to interview on the reasons behind the continued fierce kidnapping, violence, terrorism, and war before. This in itself is a new ground, and thus, strengthens our claims to originality. The paper attempted to examine the factors that led to violence, terrorism, and war. It also tried to advance the discourse to a critical level of reflection by providing insight into the unhealthy interplay of a wider interest that conspired in various ways to shape and influence the youth's restiveness in the Southern region.

We have provided a good proof that kidnapping, violence, and terrorism has its roots in the young men whom the political elites armed to rig elections. These youths were armed and promised heaven on earth to perpetuate electoral frauds and later are ignored. They, therefore, resorted to self-help and launched a new career as kidnapping for ransom. The paper has shown that frustrating conditions have affected the lives of many individuals and shaped the behavioral pattern of large social groups in the region.

With facts and clearer perspectives, the paper has shown that when people are frustrated and are denied dignity, resistance and revolution becomes inevitable. The paper has shown that there is a logical correction

among frustration, kidnapping, and economic downward spirals in the region. It shows that awful human 
conditions are capable of pushing sane persons to the outer limits of sanity. Likewise, decent individuals can change and behave in rebellious manners due to hardship and despair.

\section{References}

Amnesty International. (2004). Making violence against women count: Facts and figures. USA: Amnesty International New York.

Amaraegbu, D. A. (2011). Violence, terrorism, and security threat in Nigeria's Niger Delta: An old problem taking a new dimension. African Journal of Political Science and International Relations, 5(4), 207-217.

Berkowitz, L. (1989). Frustration-aggression hypothesis: Examination and reformulation. Psychological Bulletin, 1(106), 69-73.

Brown, C. (2007). The new terrorism debate alternatives. International Journal of Relate (Fall \& Winter), 354(6), 28-43.

Buzan, B. (1997). Rethinking security after the cold war cooperation and conflict. Cooperation and Conflict, 32(1), 5-28. Doi: 10.1177100108367903200100132(1)

Chinwokwu, E. C. (2012c). History and dynamics of terrioism in Nigeria: Socio-political dimention. International Journal of Innovative Research and Development, 1(11), 419-446.

Chinwokwu, E. C., \& Arop, S. K. (2014). Socio-psychological effects of political violence on gender in Nigeria. Meditranean Journal of Social Sciences, 5(26), 44-50.

Cohen, J. A. (2006). Necessity, political violence and terrorism. Retrieved April 2017, from http://www.usafric.com/necessity-political-violence-and-terrirosm/pdf

Cohen, A. (2008). The U.S. should oppose Hezbollah and its Iranian and Syrian masters in Lebanon. Centre for Foreign Policy Studies, 1-3. Retrieved March 2018, from http://ww.heritage.org/research/middle east/wm1922.ifm

Crenshaw, M. (1981). The causes of terrorism. Comparative Politics, 13(4), 379-399.

Dahrendorf, R. (1958). Out of Utopia: Towards a reorientation of sociological analysis. American Journal of Sociology, 2, 133-147.

Davidson, I. (2010). Nigeria: Stunting economic growth and development in South East. THIS DAY, June 13.

Dolland, J., Miller, N. E., Doob, L. W., Mower, O. H., \& Sear, R. (1939). Frustration and aggression (p. 1). New Heaven: Yale University Press.

European Union Election Observation Mission to Nigeria. (2007). State and Federal elections, 14th and 21st, April.

Galtung, J. (1969). Violence, peace, and peace research. Journal of Peace Research, 6.

Golder, B., \& Williams, G. (2004). What is terrorism? Problems of legal definition. Journal of UNSW Law, 27(2), $270-295$.

Gurr, T. R. (1970). Why men rebel (p. 24). Princeton, NJ: University Press.

Haralambos, M., \& Holborn, M. (2008). Sociology: Themes and perspectives (7th ed., p. 93). London: Harper Collins Limited.

Human Rights Watch. (2003). The Warri crisis. Fuelling Violence, 15(18).

Human Rights Watch. (2011). Nigeria post election violence killed 800. Human Rights Watch 1350, Fifth Avenue, $34^{\text {th }}$ floor New York. Retrieved from http://www.hrw.org

Human Rights watch. (2014). Nigeria: 1000 killed in central Nigeria (p. 3). Premium Times, April, 15.

Idyorough, A. E. (2005). Gender, concepts and issues in Nigeria (p. 2). Markudii: Aboki Publishers.

Jenkins, B. (1990). International terrorism: The other world. In C. Kegley (Ed.), International terrorism characteristics, causes, controls(pp. 27-33). New York: St. Martin’s Press.

Marx, K. (1977). Communism and the Arugusburger Allegemeine. In D. McLellan and M. Karl (Eds.), Selected writings (pp. 20-21). New York: Oxford University Press.

Mazefsky, C.A., \& Farrel, A. D. (2005). The role of witnessing violence, peer provocation, family support and parenting practices in the aggressive behaviour of rural adolescents. Journal of Child and Family Studies, 14(70), 71-85.

Merrian Webter's Dictionary. (1998). Merrian Webster (p. 1). Springfiel: Massachusetts, USA.

NEPAD. (2008). Nigeria government and development (pp. 7-33). Report of the New Partnership for Africa's Development.

Ngwama, J. C. (2014). Kidnapping in Nigeria: An emerging social crime and implications for the labour market. International Journal of Humanities and Social Science, 4(1), 123-145.

Niger Delta Project for Environment, Human Rights and Development (NDPEHRD). (2004). A brief report: The small aims project-A harvest of guns. FEMA: Terrorism research (pp. 5-6). Retrieved February 2016, from http:www.fema.gov/harzard/terrorism/index.shtm 
Nwolise, O. B. C. (1997). ECOMOG, peace keeping operation in Liberia: Effect of political stability in the West African sub-region-African review. Journal of National Defence College, 1(1), 36-60.

Obasanjo, O. (2002). Political thurgery and violence in Nigeria: The bane of women participation in politics (p. 50). Retrieved March 2015, from htt://www.articlesbase.com/politics-article-political-thurgery-and-violence-in-nigeria-the-bane

Obe, E. (2012). Boko harm leaders defends attacks. The Punch, January 8.

Obi, C. (2009). Nigeria's Niger Delta-understanding the complex divers of conflict in African development. The Swedish Defence Research Agency (F01) and the Nordic Africa Institute (NAI) Lecturer Series on African Security, 33(2), 3.

Okolie A. M. (2008). Child soldering and African security in the Post Cold War international relations: Lessons from democratic Republic of Congo. Journal of Liberal Studies, 12(1-2), 51-63.

Olaosebikaan, D. (2011). Jonathan and unfolding Afghanisyaization of Nigeria (p. 17). National Mirror, June, 3.

Omoweh, D., \& Okanya, D. (2005). Community unrest and threat to Nigeria’s national security. In U. J. Ogwu (Ed.), New horizon for Nigeria in world affairs (pp. 293-311). Lagos: NllA.

Oraegbunam, K. E. (2006). The metaphysical foundation of contemporary armed conflict: Implications for human dignity and global peace. In I. Odimegwu, G. I. C. Ezeani and F. Aghamelu (Eds.), Philosophy, democracy and conflicts in Africa (pp. 218-232). Awa: Department of Philosophy.

Osaghae, E. E. (1995). The Ogoni uprising: Oil politics, minority agitation and the future of the Nigeria state. African Affairs, 94(376), 325-344.

Osaghae, V. (2015). Causes of Nigeria unrest and conflict situations. In Proceedings of their 3rd International Conference, July, 2017 (pp. 28-50). Dubai, UAE.

Perouse de Montclos, M. (2011). Nigeria-watch: The third report on violence in Nigeria (2006-2011) (p. 7). Abuja: Nigeria Watch.

Quota, S., Punamaki, R. L., \& El-Sarraj, E. (2008). Child development and family mental health war and military violence: The Palestinian experience. International Journal of Behavioural Development, 32(4), 310-321.

Sagi-Schwartz, A. Seginer, R., \& Abdeen, Z. (2008). Chronic exposure to catastrophic war experiences and political violence: Links to well-being of children and families. International Journal of Behavioural Development, 32(4), 257-269.

Said, E. (1988). American intellectuals and Middle East politics: An interview with Edward W. Said. Interviewer Bruce Robbins (Social Text), 1(20), 37-53.

Salawu, B. (2010). Ethno-religious conflict in Nigeria: Causal analysis and proposals for new management strategies. European Journal of Social Sciences, 13(3), 345-353.

Soriwei, F. (2012). Boko Haram Plans to take over North-FG. The Punch, January 18, 8.

Stavrou, V. (1993). Psychological effects of criminal and political violence on children. The Child worker, 11(7), 3-9.

Sun News. (2010). How Osisikankwu was killed. Retrieved from http://www.sunnewsonline.com/webpages/features/newonthe hour/2010/dec/14/newsbreak-14-12-2010-oct.stm

Theodore, M. (1998). Crimes and accountability in Shakespeare. American Journal of Literature, 1(5), 92-95.

United Nations. (2000b). The state of world population 2000. United Nations General Assembly, fifth-fifth session. United Nation Population Fund, UN.

Walker, A. (2008). Blood oil dripping from Nigeria. Retrieved from http://news.bbc.co.uk/1/hi/world/africa/7519302.stm

Young, R. (1977). Revolutionary terrorism, crime and morality. Sociological Theory and Practice, 4, 287-297.

Zartman, I. W. (1991). Conflict reduction, prevention and resolution. In F. M. Deng and W. I. Zartman (Eds.), Ethnic violence threatens Nigeria's democracy (p. 300). New York: Sage. 